\title{
Relational Experiences of Power and Gender for Nurse-Managers of Private Hospitals
}

\author{
Maria José Menezes Brito ${ }^{1}$ \\ Lívia Cozer Montenegro \\ Marília Alves ${ }^{3}$
}

\begin{abstract}
Influenced by increased technology and globalization, Brazilian hospitals are undergoing significant changes. The managerial models focused on the male model are being slowly and gradually replaced, with an expressive participation of female nurses in management positions. Thus, we aimed to uncover some aspects of the relational experiences of power and gender of nine female nurse-managers working in four large and medium-sized private hospitals in Belo Horizonte, MG, Brazil, through a qualitative case study. The results show that management discourses value a managerial style focused on the organizations' humanized aspects, where authoritative styles have no space. In this scenario, the work of female nurse-managers strengthens teamwork, which improves their image and contributes to forming their identity.
\end{abstract}

Descriptors: Management; Gender Identity; Nursing.

\footnotetext{
${ }^{1}$ RN, Ph.D. in Management, Adjunct Professor, Escola de Enfermagem, Universidade Federal de Minas Gerais, MG, Brazil. E-mail: brito@enf.ufmg.br.

2 RN, Master's Student, Escola de Enfermagem, Universidade Federal de Minas Gerais, MG, Brazil. E-mail: livinhamontenegro@hotmail.com.

${ }^{3}$ RN, Ph.D. in Nursing, Full Professor, Escola de Enfermagem, Universidade Federal de Minas Gerais, MG, Brazil. E-mail: marilix@enf.ufmg.br.
}

Corresponding Author:

Lívia Cozer Montenegro Universidade Federal de Minas Gerais. Escola de Enfermagem.

Rua Alfredo Balena, 190 Setor Saúde sala 514

Bairro Santa Efigênia

CEP: 30130-100 Belo Horizonte, MG, Brasil

E-mail: livinhamontenegro@hotmail.com 


\title{
Experiências relacionais de poder e gênero de enfermeiras-gerente de hospitais privados
}

Influenciados pela crescente incorporação de tecnologias e pelo movimento de globalização, os hospitais brasileiros estão passando por mudanças significativas. Os modelos gerenciais, centrados na lógica masculina, vêm sendo substituídos de forma lenta e gradativa, com a participação, cada vez mais expressiva, de enfermeiras em cargos gerenciais. Nesse sentido, buscou-se, aqui, apreender aspectos das experiências relacionais de poder e gênero de nove enfermeiras, no exercício da função gerencial, em quatro hospitais privados de médio e grande porte da cidade de Belo Horizonte, MG, Brasil, por meio de estudo de caso qualitativo. Os resultados evidenciaram que os discursos da gestão têm valorizado a atuação gerencial voltada para os aspectos humanos das organizações, não havendo espaço para a figura autoritária do gerente. Nesse cenário, a atuação da enfermeira-gerente demonstrou fortalecimento dos laços entre a equipe, implicando na melhoria da sua imagem e contribuindo para formação da sua identidade.

Descritores: Gerência; Identidade de Gênero; Enfermagem.

\section{Experiencias de relaciones de poder y género de enfermeras administradoras de hospitales privados}

\begin{abstract}
Influenciados por la creciente incorporación de tecnologías y por el movimiento de globalización, los hospitales brasileños, están pasando por cambios significativos. Los modelos de administración centrados en la lógica masculina vienen siendo substituidos de forma lenta y gradual, con la participación, cada vez más expresiva, de enfermeras en cargos administrativos. En este sentido, buscamos aprender aspectos de las experiencias de relaciones de poder y género de nueve enfermeras en el ejercicio de función administrativa en cuatro hospitales privados de medio y gran porte de la ciudad de Belo Horizonte, MG, Brasil, por medio de un estudio de caso cualitativo. Los resultados evidenciaron que los discursos de la administración han valorizado una actuación administrativa dirigida hacia los aspectos humanos de las organizaciones, no habiendo espacio para la figura autoritaria del administrador. En este escenario la actuación de la enfermera administradora demostró un fortalecimiento de los lazos entre el equipo, implicando en la mejoría de su imagen y contribuyendo para la formación de su identidad.
\end{abstract}

Descriptores: Gerencia; Identidad de Gênero; Enfermeria.

\section{Introduction}

The current set of organizational innovations has currently pressured organizational leaders to manage based on promoting competitiveness and economic efficiency when recognizing the need for new alternatives to organize the delivery of their services. From this perspective, Brazilian hospitals, regardless of their nature, size or type of service, are undergoing significant changes, which have intensified in recent years, given financial pressures and the need for restructuring in order to manage the complexity of organizational resources.
For that, the managerial models that prevail in hospitals have been guided by various characteristics, based on determinants that include, among others, the growing costs of health care, the need to increase the coverage of services, and the increased demands of clients. In this respect, the patriarchal model centered on the male perspective, has been replaced in a slow and gradual manner, including in managerial boards, and in other fields, such as business administrators, engineers, economists, nurses and physical therapists. When these 
professionals assume management positions, whether these are strategic or intermediate, they play different roles and have different statuses, which leads to changes in the relations of gender and power(1).

Given the complexity of activities performed by a manager in the current context of organizations, we need to stress his/her importance as an agent of change. This fact leads us to reflect that the system of description and interpretation of the world based on the categories of management is rooted in the modern social experience, which implies managing emotions, time, relationships and image ${ }^{(2)}$. Because managerial work is considered a singular activity, identity emerges as a central concept in organizational studies. A managerial identity is constructed according to specific contexts of action, relating roles and formal profiles of what is attributed to it ${ }^{(3)}$. Hence, the process of constructing identity involves essential aspects that occur in a sequence, that is, "learn what it means to be a manager; develop interpersonal judgments; acquire self-knowledge; and fight against tension and emotion"(4). Reflecting on new identity configurations in hospitals is important because these are marked by traditional values and characteristics, in which most of the involved individuals resist changes, since changes in relations of power may occur. When routine practices in the hospital sector are analyzed, the increased participation of female nurses in managerial positions is observed, both in the public and private sectors ${ }^{(5)}$. We stress that one of the main characteristics that differentiates nursing from most of the other professions and that influences the nurses' professional roles in their multiple relationships is the fact it is a profession where women predominate. Thus, the occupation of managerial functions by women suggests changes in their identity and different configurations of relationships of power and gender. One needs to take into account that a situation that generates conflict and undefined roles in nurses' work is related to the fact they both exercise managerial functions and provide care, assuming a vast set of activities such that prioritizing and reconciling them is virtually impracticable. In relation to the undefined roles and true responsibilities of a nurse, a historical legacy in which negative feelings such as a lack of pride and low self-esteem persists and which accrues mainly from a lack of identity, is evidenced(6). To support and enrich the analysis of the identity configuration of female nurses in managerial positions this study identifies the subjective aspects of the relational experiences of power and gender in the context of private hospitals.

\section{Method}

This paper is part of a larger project entitled: "Management practices in family and non-family hospitals in Belo Horizonte: a perspective on gender and power", which was a qualitative case study, the main participants of which were nine nurses in management positions. The Case Study is used as research strategy in organizational and managerial studies, greatly contributing to the understanding of complex phenomena at the individual, organizational, social and political levels, allowing the preservation of significant characteristics of real life events(7). In this case, the use of a probabilistic sample was not appropriate and intentional sampling or rational choice was used( ${ }^{(8)}$. Hence, the definition of the sample was based on the researcher's sensitivity to and knowledge concerning the context to be studied.

Data were collected through semi-structured interviews in four large and medium-sized private hospitals in Belo Horizonte, MG, Brazil. The study complied with the ethical recommendations of Resolution 196/06.

Data analysis followed the content analysis technique $^{(9)}$ and included the following stages: preparation, in which the interviews were transcribed verbatim according to the interview script; re-reading of the material; and organization of reports and transcription of tapes. The consecutive stages were performed to achieve categorization through relevance criteria(9), which departs from the classical orthodoxy of positivist research and opens up the possibility of searching for the essence of a phenomenon ${ }^{(9)}$, as presented in the following results.

\section{Roles overlap in the exercise of the managerial function}

The analysis of relational experiences of gender in the managers' workspace revealed that professional and domestic roles overlap. Feminine singularities, issues related to motherhood and also the children's age, are evidenced in the reports and influence on the nurse-managers' professional role, requiring the use of support strategies in the family sphere as shown in the following report: I have a structure otherwise I wouldn't be able to manage it. My daughters are 7 and 8 years old and they are super independent. They already know how my life is. So, we have our entire day organized. My husband helps me a lot; we have a housemaid. So I have to have a very good structure and things have to work in this structure. Otherwise, I'm really not able to manage it (G6). It is still believed that the place 
socially destined for women is the family, "it is at home where she will primarily find personal realization"(10). Motherhood still is the main and defining component of women's identity and is one of the few permanent and universal elements of the gender-division of work. Women are mainly defined in our society as wives and mothers, whereas men are defined in terms of their occupation.

Hence, the ability to overcome difficulties and achieve professional success is considered a sign of personal maturity and stability as observed in the following report: I guess it is maturity, an issue of personal stability. I have a entire structure, I have a family, and I feel alright, I feel secure in relation to the job market! I guess that all these help me to develop a good job and be recognized for it (G6). Differences between men and women are highlighted in relation to the perceptions and forms both relate to professional success. For men, what matters is to have professional success, to achieve social acknowledgement at work and, consequently, have a good financial return to obtain objects of consumption (11). We add that "senior executives used to say that to become a successful professional, one needs to sacrifice leisure and family life and dedicate one's full time to work"(11). On the other hand, for women, "success includes balancing profession, children, husband and leisure", even though reconciling all these implies a triple workload. Additionally, financial independence frequently results in conflicts of interest with the partner, generating "economic and emotional independence". This study indicates that balancing issues in the private and public spheres is a concern among nurse-managers.

Another aspect to be observed in the reports is related to their high level of commitment to their managerial function and with the organization: $I^{\prime} m$ a person who doesn't miss work because I don't permit myself to. So, even if I have a temperature, I come to work, you know? I didn't miss even one day this year. So I'm very rigorous with myself (G6). This report reveals the excessive effort and overload assumed by the interviewee, reflecting her posture of donation in performing her management function. However, commitment to work is possible only when a support structure exists in the private sphere. Another manager confirms this situation: Thank God, my mother-in-law takes care of my baby. She lives near my place. And my husband also takes care of the baby when he gets home, he has a fixed schedule! He works until five and can watch the baby when he gets home. So I say thank God I have her to watch the baby for me, she's not just any person, it's reassuring, you know? Because if it was a nanny, she'd have a certain schedule to cover, time to leave. And having my motherin-law facilitates a lot! Wow, if it wasn't for her I guess it'd be very complicated (G4).

It is interesting to note that the manager's husband has a fixed schedule at work but this is not the same for her, which signifies there is a rupture in the structure of relational experiences of gender. Role changes are then observed with the inclusion of women in the job market, with an emphasis on managerial functions. However, tension experienced by the interviewee is apparent when she considers the possibility of not having the support of other people from her family, such as the mother-in-law and her husband so that she can carry on with her professional life. This tension is related to the dependency of the nurse on a "nanny", that is, a person who can really replace her in the domestic functions so that she can perform her professional role without regard to personal favors. It shows that when women occupy managerial functions they have to deal with contradictory and conflicting demands that involve aspects related to their professional tasks, femininity, motherhood and marital and social lives, which result in overload and a certain "identity crisis"(11). Identity crisis is "seen as part of the broader process of change, change that is dislocating central processes and structures in modern societies and shaking references that provide a stable anchor to individuals in the social world"(12).

The reports of the studied managers permits inferring that an "identity crisis" is on-going and has been marked by a transitional phase through which managerial models of hospitals have been going through with important dislocations of individuals involved in productive processes in relation to a hierarchical position and, thus, relations of power. As a way to minimize this crisis, managers develop mechanisms of reconciliation between work and private life, which confer on them the ability to organize life at home and at work. This organization depends on variables such as children's age, which reflects the maintenance of traditional characteristics of society, in specific cases, the primary participation of the mother in children's education. From this perspective, the interviewee considers herself "unnecessary" in the current life of their children: I manage to organize myself pretty well! But it coincides with my daughters not being so little, in a phase when I'm not so necessary. I managed to organize my life so that I spent all nights and weekends with them. And in a period when they needed me most, I had my maternity leave. I have divided my time pretty well. I manage to administrate things at my home in a very smooth way; I delegate functions to people. I'm very satisfied 
with what I do, I never neglect my affective life. My life at home would mix with my life here and now I manage to deal with this very well. Off course I have my "neuroses", my difficulties, but like, today I guess I've attained maturity, I manage to deal with this very well (G6). This report evidences the difficulties experienced at the beginning of the career as well as its evolution and "maturity" over time. In relation to this aspect, we draw attention to the "motherhood model" in which some workers include themselves ${ }^{(13)}$. For them, the family comes first; it is that which determines their lifestyle, which is based on balance between the private and professional spheres. Hence, the manager's view of world is organized around their desire to keep their jobs, which is primarily determined by the family choices and needs, making their job a secondary element in their lives and which should not put family harmony at risk.

Despite the overload of responsibilities at work and at home reported by interviewee G6, she has attained certain maturity and assimilated her activities and administration of her life, which seems to be an accomplishment that accrues from her professional experience. Some authors ${ }^{(14)}$ have considered the increased level of responsibility as part of the process of modernization of organizations. This situation is a consequence of downsizing hierarchies and professionals who are kept in the organization, especially those who compose the managerial team, accumulate tasks. In this context, some "moorings" are identified in the context of the managers' routine that reflect cultural traces and gender inequalities: What I explained to my family at home is that this is a function that demands much more from me. I explained it to them, so as they get prepared for when I need to return home later, or something like that, so that they start to assume some responsibility for when their mother is busy. I count on my family; there's the help of this person who lives with me and my mom supports me. My husband also works near home. $\mathrm{He}$ is autonomous so it's easier for him to work things out (G5). The interviewee explains herself to people to whom she is related and "prepares them" for potential delays, reflecting social inequalities of gender. This situation allows us to demonstrate the phase of social transition and identity of femininity in a phase of consolidation. Hence, at the same time in which advancements and ruptures are identified in social models, behaviors that reflect a patriarchal culture are still observed. The masculine order, which has dominated for thousands of years, is gradually no longer a hegemonic reference for culture and power, opening new spaces for women, in the government, companies, families and even in the armed forces. Perhaps the strongest effect of modernity is the decline of paternal power and patriarchal society that resulted from $i^{(11)}$.

\section{Feminine characteristics as competitive advantage: the perception of nurse-managers}

Feminine competencies emerged from the reports, reflecting a relational dynamics of gender and which become facilitating elements in the managerial function. These competencies, from the perspective of the managers, teamwork as follows: I believe that women are shrewder, are in better more condition, good sense, and some facilities: they deal better with the team, with delegating functions, dictating standards, demanding. I don't think men deal so well with these issues. I think women manage to control the team better. I see it clearly in my daily routine. If you compare me with (the male nurse), it's completely different, absolutely different! I have my team under control! You know, that thing of leading, demanding, being there (G6). The identification of female characteristics and their influence on the team mark the report of $\mathrm{G} 6$ and reveal that the female characteristics are a competitive advantage in the current context of organizations. In the managers' views, the particularities indicated are not restricted to nursing and can be seen in other work situations: My experience shows that men have more difficulty dealing with power, reprimanding, warning. It is not specifically here. I've already been a technical expert responsible at a school and I used to deal with a large number of professors. They thought of themselves as unattainable beings! So you have to keep a very firm posture with them in relation to the daily schedule, routine and I've always had it, it was easy for me. A men replaced me and it's amazing the difficulty he has to deal with things, so I guess it's related to gender, for sure! It's a huge difficulty to reprimand someone, to say things. So, they play themselves: "this is a women's thing!" So I guess it perhaps is related to culture (G6). The previous report shows that some characteristics inherent to women are appointed as facilitating elements to exercise management, which can also be observed in the banking sector(15). Additionally, the interviewee recognizes characteristics linked to gender, highlighting their complexity and potential cultural issues that involve this matter. Differences of gender are then reinforced: I don't see it as a matter of male chauvinism. It's gender. For example, men don't pay attention whether you had a manicure. This visual perception of details is inherent to women. I found it very funny when Dr. (...) was talking about a negotiation, regarding the daily nursery fee, $\mathrm{He}$ didn't even notice and I say: "it's missing!" and he said: "This is a woman's thing". But I guess that this detail thing, of observing things is a woman's thing (G9). 
In the specific case of nurse-managers, the fact of being a woman and performing an activity in a sector predominantly female is a comfortable situation and seems to reinforce the feeling of identification with the profession: Female nurses strongly identify themselves! The female nurse identifies herself a lot with the profession. The issues of care, zeal, I think it is very characteristic of women (G3). From this perspective, the interviewee relates nursing as a female profession, and in opposition to the position of some authors ${ }^{(13)}$, states the careful and dutiful characteristics of women are positive elements for management, being a differential when compared to other professions. It is therefore, the expression of female characteristics and their power in the workplace.

\section{The feeling of belonging as a facilitating element in managerial practices}

An evaluative feeling was observed in the reports and it assumed a facilitating character in the context of managerial practices, stressing the commitment of managers to the organization: I've always devoted myself a little more. Sometimes I'd come here on Saturdays. I work from Monday to Friday, but I came to arrange something I had left pending and that I didn't want to leave for Monday. I came even part-time to see whether someone was needing something, because sometimes we'd be out of material, or the physician would attend patients in the outpatient clinic, you know, to check whether the material was really going to be delivered (G5).

The managers' commitment and involvement are observed through the broadening of their set of responsibilities and therefore, the need to intensively dedicate themselves to organizational issues. However, instead of bothering them, this situation elicited feelings of pride, satisfaction and professional realization. Some aspects linked to nursing's historical evolution deserve to be highlighted because a spirit of giving and vocation marks the profession. This historical characteristic of nursing seems to influence the managers' need to supply, as much as possible, the organization and to perform their work exempt from any questioning by the team, superiors or from themselves. Hence, work has priority over the remaining daily needs and management has priority in the life of managers and becomes "part of it": The management function has been always part of my life. I got my degree and eight months later I got this position. So, it got really strong and present in my professional life. I never stayed in care delivery for long. I, my professional life was always in this function, so I established a way of being (G3).

The importance $\mathrm{G} 3$ attributes to her personal characteristics and their influence on how she performs routine actions and managerial practices is observed. The position she assumes legitimates the managerial focus as social practice. From this perspective the nurses' identity configuration influences managerial actions and transforms them and has been changed over their lives' trajectory. The studied managers expressed divergent positions in relation to managerial practices since they reveal commitment and investment in the organization, which frequently implies personal loss and exacerbated dedication, considering they frequently maintain their responsibilities in the domestic sphere. Hence, managers keep feminine characteristics and devote themselves as much or more than men to professional and organizational issues. This individual and organizational diversity permit them to make better decisions in the management function, grant flexibility, and favor creativity and innovation through the use of shared values(16). This finding indicates the studied group is professionally mature since it has acquired a prominent space in the job market where there is no place for uncompromising postures.

Feelings related to availability, affinity and ability to deal with managerial issues, mastery, tranquility and leadership, ability to interact, to establish relationships and networks, being attracted to new things and the ability to face challenges, also emerged from the reports. The characteristics described were considered essential for the exercise of managerial practices: I guess that because of my availability, knowledge of the sector, being there 24 hours and aware of the hospital's problems. I guess that we have greater affinity, more power to deal with it! It's more because of the time you make available and the proximity you have with the others, with the support services, with the other employees in the hospital, I guess that's it (G1).

G1's report reflects her availability to fulfill the role of a manager. For this activity to be completed, some authors stress that the involvement of different professionals in the performance of managerial practices requires preparedness, vocation and availability of time(17). Positive feelings of belonging reinforce the nurses' commitment to the organization, professionalism and overcoming stereotypes linked to women managers in the face of the job market's new demands. The affinity of nurses for managerial issues is linked to factors of technical and personal natures. The relevance of technical knowledge is emphasized by the manager and is related to academic education, which is considered essential for the performance of managerial practices as exemplified in the G5 interview's excerpt: To be a nursing coordinator you have to be a nurse. I guess that there's no 
other way. You know the difficulties experienced by nurses and auxiliaries. The need an auxiliary has for having a nurse around, sharing experiences with her. Even nurses, you have a nurse coordinator and sometimes there's a problem: The physician is complaining of this, of what I do, what do you think? What should I do? (G4).

Nurses recognize the distress the nursing team experiences and acts as a mediator in daily conflicts between different professionals. Informal relationships and affective ties are established as a way to minimize the problems experienced in the daily routine. This type of relationship and identification with the organization is essential for exercising the management function and strengthening personal and organizational bonds. Reflecting on the social and organizational context in which the nurse is included leads this professional to the possibility of becoming a critical element in relation to the institution and the organization of nursing workers itself ${ }^{(18)}$.

The managers highlighted their individual profile and ability to learn as essential elements for their professional performance: The profile varies a lot! You'll find many nurses in the market who are not able to work in as managers. I guess it's a competence the person has to seek, to update knowledge, see the institution from the inside, what it wants us to develop (G8).

We have to pay attention to the confrontation of the manager with organizational demands and those of the job market, what motivates her to continuously update her knowledge. The need to meet the hospital's expectations is also apparent in the same report, reinforcing the presence of ideological mechanisms of identification with the organization.

Another aspect in the managers' reports that stands out is their ability to relate with people, to use her 'political knowledge' in diverse relationships, be emotionally stable, determined and professional. These feelings reflect the different fields of action and of the managerial role as described in the following: The issue is also one of interpersonal relationships. I guess that it is it, especially in a closed sector, it's essential, you have to have a good relationship with everyone! Politics; making nice, really! I guess you have to be political, you must know when to make a decision, when to retreat, sometimes you have to retreat. Here at the hospital, I like people in general, we end up living with everyone, not only with people from the surgical Center (G2).

G2 emphasizes the importance of interpersonal relationships and the establishment of contact networks with different professionals in the internal and external spheres. Under this view, managers believe they are an important "link" between the subordinates and the hospital direction as they are attuned to the administrative demands in the current context, in which the manager plays an important role in facilitating the link between sectors and people: I arrive at the hospital and people come to me a lot and bring a lot of issues to be resolved. There are things in the daily routine that I authorize, things to buy, to evaluate, particularities of each sector, the managers come to me. We work very closely, people ask for my opinion. I'm the link among the managers, the employers, the management and the direction. All the issues the directory has to authorize usually pass through me first. I listen to what is ok, what meets the needs, what is needed, I go after solutions, try to help, do the best I can (G9).

The managers' work routine is essential to understanding the main characteristics of a feminine management style. Among these characteristics the following are highlighted: sensitivity, innovation, integration, emotionality, intuition, creativity, ability to perceive details, discipline, sense of justice, patience, organization, hard work and perception. The managerial discourse currently emphasizes more participation, values those managers more concerned with the organization's humanized aspects, favoring women because they are accessible, which contributes to strengthening ties among the remaining team members.

\section{Final Considerations}

The relational experiences of nurse-managers reveals there is an overlap of professional and domestic roles, and the adoption of strategies to reconcile the professional and private spheres is necessary, mainly involving family support. The nurses' managerial practices have implications for the organizational, professional and personal spheres.

In the organizational sphere, they contribute to hospital development through motivating employers, integrating the team, and reducing losses in the different hospital sectors. In the professional sphere, implications are associated with the construction of their identity and improved image, while managerial practices are elements that determine visibility and professional status and are considered an achievement in nursing. In the personal sphere, the influence of family relationships marks their lives' trajectories, initially in care delivery and then as managers.

They hold that relational experiences of power run smoothly with the remaining team members, which reflects their maturity and learning acquired in their 
roles as managers. A feeling of belonging was identified and emphasized as an essential factor of professional legitimatization because they involve commitment to the responsibilities of their professional roles, resulting in the need to intensively dedicate themselves to organizational issues. Finally, further studies addressing health organizations of different sizes and fields considering their cultural and historical heterogeneity, involving different professions, are important to complement research in health and the intense relations of power that characterize hospitals. Bringing up issues that permeate nurses' managerial work is important to unveil values that are involved in the social practice of nursing because it strengthens the nursing profession and enables the development of competencies according to current organizational demands.

\section{Reference}

1. Brito MJM. A configuração identitária da enfermeira no contexto das práticas de gestão em hospitais privados de Belo Horizonte. [Tese de doutorado]. Belo Horizonte (MG): Faculdade de Ciências Econômicas da Universidade Federal de Minas Gerais/UFMG; 2004.

2. Chanlat JF. Modos de gestão, saúde e segurança no trabalho. 3.ed. Petrópolis: Vozes; 2000.

3. Esther AB. A Construção da identidade gerencial dos gestores da alta administração das universidades federais em Minas Gerais. [Tese de doutorado]. Belo Horizonte (MG): Programa de Doutorado do Centro de Pós-Graduação e Pesquisas em Administração da Faculdade de Ciências Econômicas da Universidade Federal de Minas Gerais/UFMG; 2007.

4. Hill L. Os novos gerentes: assumindo uma nova identidade. São Paulo: Makron Books; 1993.

5. Brito MJM, Monteiro PR, Costa JO. Interfaces da mudança e dos modos de gestão na rede hospitalar privada de Belo Horizonte: caminhos e descaminhos na ótica da gerente-enfermeira. Anais do $16^{\circ}$ ENANPAD - Encontro Nacional da Associação Nacional dos Programas de Pós-Graduação em Administração; 2002; Salvador; Brasil; 2002.

6. Waldow VR. A opressão na enfermagem: um estudo exploratório. In: Lopes MJM, Meyer DE, Waldow VR. Gênero e saúde. Porto Alegre (RS): Artes Médicas; 1996. p.106-32.

7. Yin RK. Estudo de caso. Planejamento e métodos. 2ed. Porto Alegre (RS): Bookman; 2001.

8. Contandriopoulos AP, Champagne F, Potvin L, Denis JL e Boyle P. Saber preparar uma pesquisa: definição, estrutura, financiamento. São Paulo/Rio de Janeiro: Hucitec/Abrasco; 1994.
9. Bardin L. Análise de conteúdo. Lisboa: Edições 70; 2008.

10. Novelino AM. Um perfil idealizado. Cad Pesqui 1988; (64):21-9.

11. Betts JA. A mulher e o feminino no mundo do trabalho. AD/ verso : J Adufrgs 1998; (37, 1aquinz).

12. Hall S. A identidade na pós-modernidade. 3.ed. Rio de Janeiro: DP\&A; 1999.

13. Belle F. Executivas: Quais as diferenças na diferença? In: O indivíduo na organização - Dimensões esquecidas. São Paulo: Atlas; 2001. p. 196-251.

14. Sainsaulieu R. Sociologia da empresa. Organização, cultura e desenvolvimento. Lisboa: Instituto Piaget; 1997.

15. Melo MCLA. Gênero e poder em organizações do setor bancário: habilidades diferenciadas e desafios específicos da gerência feminina. 90 Colóquio Internacional sobre o poder local: II Colóquio Internacional el análisis de las organizaciones y la gestión estratégica. Perspectivas Latinas:2003. Salvador Brasil; 2003.

16. Mendes IAC. Aprendizagem organizacional e gestão do conhecimento: um desafio a ser enfrentado. Rev. Latino-Am. Enfermagem. maio-junho 2003; 11(3):269.

17. Cecílio LCO. Modernização gerencial dos hospitais públicos: o difícil exercício da mudança. Rev Adm Empresas. maio-jun 1997; 31(3):36-47.

18. Prochnow AG, Leite JL, Erdmann, AL. Teoria Interpretativa de Geertz e a Gerencia do cuidado: visualizando a prática social do enfermeiro. Rev. Latino-Am. Enfermagem.; julho-agosto 2005; 13(4): 583-90. 